\title{
THE FREEDOM OF CONTRACT IN PLANTATION CORE ESTATE AND SMALLHOLDERS
}

\author{
Ermanto Fahamsyah \\ Faculty of Law, Jember University \\ ermanto_fahamsyah@yahoo.co.id
}

\begin{abstract}
The Plantation Core Estate and Smallholders (PIR/Perkebunan Inti Rakyat) is a partnership scheme of the estates whereby a large estate acts as the core of development to small local farms in a mutually beneficial, integral, and continuous system. Simply put, PIR is one form of contract farming. The PIR scheme was first introduced by the Indonesia government in order to encourage the development in local farms. Moreover, the partnership system is based on patron-client relationship and regulated through a contract in which the large estate is the patron and local farms are the client. However, the PIR system involves state within the contract. The state's involvement is important so as to safeguard the interests of local farms (client) which are prone to predatory exploitation by the patron (large estate) and thus, balancing the bargaining powers of each party in the contract. This paper problematizes the contractual mechanism of PIR in respect to the freedom of contract. Thus, it can be concluded that the state's involvement in the PIR shows that the freedom of contract principles are rigged to a degree which restricts some of the patron's powers such as controls on supply and price in order to protect the local farms from being exploited.
\end{abstract}

Keywords: Core Estate and Smallholders; Plantation; Freedom of Contract

\section{Introduction}

Plantation Core Estate and Smallholders is a pattern of plantation sub-sector development to realize business integration with the aim of improving the social-economic conditions of participating farmers and supported by various production, processing, and marketing activities by using large plantation companies as the core in a mutually beneficial cooperation system. ${ }^{1}$

Relations in Plantation Core Estate and Smallholders are a mutually beneficial, whole and sustainable partnership relationship between large plantations and smallholder plantations. In addition, it has a theme or spirit of partnership which is a government initiative to create an ideal relationship pattern. However, the relationship is not familial but is carried out in a straightforward manner through a certain mechanism in the presence of the terms of the partnership pattern, the rights and obligations of the core company and the bank with participating farmers and stipulated in the cooperation agreement.

Therefore, a discussion of the partnership in Plantation Core Estate and Smallholders can be linked to the theory of Freedom Contracting using Jeremy Bentham's rationale and relating it

\footnotetext{
1 Surat Keputusan Menteri Pertanian Nomor 668/Kpts/KB.510/10/1985 tentang Petunjuk Umum Pelaksanaan Proyek Perusahaan Inti Rakyat Perkebunan, bagian Lampiran, Bab I. Pendahuluan, hal. 3 dan Bab II Daftar Istilah, page 7
} 
to the thoughts of P.S. Atiyah about the withdrawal of the laissez-faire concept and the freedom of contact which follows below.

\section{Result and Discussion}

Freedom to contract is the freedom of the parties in an agreement to compile and agree to the contents of the agreement, without interference from the State. ${ }^{2}$ Freedom to contract is much influenced by the development of free market ideas pioneered by Adam Smith and Jeremy Bentham with the notion of utilitarianism. ${ }^{3}$ Utilitarianism and the classical economic theory of laissez-faire are considered to be complementary and together revive the thoughts of individualistic liberals. The understanding of utilitarianism from Jeremy Bentham is closely related to classical political economy. ${ }^{4}$ Both believe that individualism is a social value and mechanism, and freedom of contract is considered a general principle. Utilitarianism from Bentham has a close relationship with classical economic politics. A.W. Coast explained that during the period 1770-1870 utilitarians and adherents of classical economics were "complementary and mutually reinforcing the thinking of individualistic liberal schools". ${ }^{5}$ They spread the beliefs of individualism as social values and mechanisms, and they believe freedom of contract is a general principle. Both of these understandings accept the idea that humans generally understand their own best wishes, they give maximum priority to wealth and pleasure regardless of how wealth and pleasure are distributed. ${ }^{6}$

Jeremy Bentham also explained that no one can know what is good for the sake of one's self except themselves. Actually, the limitation of freedom of contract is the limitation of freedom itself and all restrictions on freedom are not justified and if you want to do so requires justification. Bentham also explained that the government should not interfere in individual interests if the government itself did not understand it. ${ }^{7}$ Jeremy Bentham said that the parties would negotiate in agreement for their optimum good. In reality, this can only be achieved if both parties have the same training position or bargaining position. ${ }^{8}$ Though the bargaining position of participating farmers and core companies is not the same, where participating farmers

\footnotetext{
${ }^{2}$ P.S. Atiyah, The Rise and Fall of Freedom of Contract, (Oxford: Clarendon Press, 1988), page 697-711.

${ }^{3}$ Ibid., page 324 .

${ }^{4}$ Ibid.

${ }^{5}$ Ibid.

${ }^{6}$ Ibid.

${ }^{7}$ Ibid., page 325. Look Sutan Remy Sjahdeini, Kebebasan Berkontrak Dan Perlindungan Yang Seimbang Bagi Para Pihak Dalam Perjanjian Kredit Bank Di Indonesia, (Jakarta: Institut Bankir Indonesia, 1993),page. 24.

${ }^{8}$ P.S. Atiyah, op.cit., page 324 and 614.
} 
have a weak position. To overcome this, the state intervened to protect the weak through regulations.

Gladstonian liberalism in its development has been replaced by Asquithian liberalism. At that time there was also an increase in attention towards the poor, the willingness to make statutory legislation to increase, and the people who received legislation that paid more attention to the interests of the community also increased. The principle of freedom of contract and laissez-faire that supports the interests of groups of entrepreneurs and industry to be free from the role of state regulation is no longer a symbol of Liberals and Radicals. The principle of freedom of contract and laissez-faire is considered only a slogan of conservatives who demand the absence of state interference. While the New Radicals instead demanded that more interference from the state. ${ }^{9}$

In the 1880s the principle of freedom of contract practically ended as a political slogan. Some evidence shows that this has become the view of politicians, political theorists, philosophers and drivers of social reform. ${ }^{10}$ Economists argue that freedom of contract will provide maximum benefit if there is a distribution of welfare. If the distribution of welfare is unfair or unsatisfactory, what is produced by the agreement will reflect that injustice or dissatisfaction. $^{11}$

In its development, it turned out that the classical model agreement had failed. This is evidenced by the amount of state intervention in freedom of contract through legislation produced by the British Parliament since $1870 .{ }^{12}$ The aforementioned conditions can apply in the relationship between core companies and banks and participating farmers in the implementation of Plantation Core Estate and Smallholders. Core companies and banks have the opportunity as parties with a stronger bargaining position than participating farmers. This imbalance of bargaining position often gives rise to agreements between core companies and banks with participating farmers who are one-sided or lame, unfair and violate propriety rules. So that the state needs to intervene to protect the weak parties.

Based on the problems mentioned above, the theory related to contracting freedom is expected to help analyze the mechanisms and partnership relationships in Plantation Core Estate and Smallholders between the parties involved, especially the core companies with participating

\footnotetext{
${ }^{9}$ Ibid., page 583-585.

${ }^{10}$ Ibid., page 587.

${ }^{11}$ Ibid., page 614 .

${ }^{12}$ Ibid., page 693.
} 
farmers and banks with participating farmers. Plantation Core Estate and Smallholders initially aimed at creating a mutually beneficial, intact and sustainable relationship between large plantations and smallholder plantations. Relationships in Plantation Core Estate and Smallholders have a theme or spirit of partnership, but the relationship is not family-based but is carried out in a straightforward manner through certain mechanisms regulated in legislation and cooperation agreements.

Mechanisms in Plantation Core Estate and Smallholders are prepared by involving state interference as outlined in the legislation. Plantation Core Estate and Smallholders are carried out through several stages and each stage has various interrelated activities and determines success, both from physical development and human resource development. Four stages in the implementation of the Core People's Plantation Company, such as ${ }^{13}$ : a. Preparation phase which includes project preparation; b. Stage of physical development, both gardens, and settlements and various infrastructure and facilities needed; c. Conversion, namely the stage of transfer of plasma plantation ownership and credit burden to selected participating farmers; and D. Postconversion, namely the development stage which includes the period of repayment of credit, fostering farmers and farming efforts towards the formation of independent farmers.

There are several important mechanisms in Plantation Core Estate and Smallholders, first, regarding Land for Participant Farmers. The land is one of the important facilities in the plantation business, including the implementation of Plantation Core Estate and Smallholders. Land for the Plantation Core Estate and Smallholders development area originates from land with state land, land owned, communal land, arable land, forest land and the land of power mining. Regarding the status of the land, except for State land, the status of the land must be changed first to be converted into plantation development areas in accordance with the provisions and procedures attached to each land status. If the development area includes a forest area, both conversion forest, and production forest, it is necessary to submit a request to release the area to the minister who has authority in the forestry sector. For forest areas, there also needs to be a replacement area. For development areas covering customary land or customary community land, an agreement or release from the customary law community is required. The development area which covers the area of mining rights must be obtained by approval or release from holders of land rights. If the development area is owned by the farmer, the arable land and customary land are settled by prioritizing the owner to become a PIR participant in the plantation

\footnotetext{
${ }^{13}$ Surat Keputusan Menteri Pertanian Nomor 668/Kpts/KB.510/10/1985, op.cit, page 5-6.
} 
and there is no compensation for the plant growing on it as long as the person is willing to surrender his land. ${ }^{14}$

Second, Credit-Aid to Participant Farmers. The credit component provided to participating farmers consisted of the cost of building a garden, a house, opening land and food crops, land certificates, garden roads and an overhead cost of 10 (ten) percent which would be borne by the participating farmers. Participant's loan distribution is divided into 3 (three) stages, such as ${ }^{15}$ :

a. Development phase

This first stage is a period for building smallholdings and other facilities and preparing farmers to become customers directly from the bank. The first period of time for rubber plants for 3 (three) years, namely the first year up to the third year from the start of the planting month. While for oil palm, coconut, cocoa, and tea for 2 (two) years, namely the first year up to the second year starting from the planting month. At this stage, the Bank has issued a credit to project implementers namely the Government cq. Directorate General of Plantation or core company.

b. Credit conversion phase

At this stage, loans that were originally channeled to project implementers were transferred to participating farmers after the feasibility assessment. At this time the farmer acts as a debtor in a credit agreement with the bank.

c. Credit repayment phase

The third stage is the period of repayment of credit, which is after the participating farmers' farm produces oil palm. The proceeds from the sale of palm oil are partly to pay off credit.

Based on the above steps, credit assistance that was originally channeled to core companies will be transferred to participating farmers at the conversion stage. The conversion itself is the stage of transferring the plasma development credit burden from the Government or the core company to the burden of participating farmers on the submission of plasma plantation ownership to participating farmers. Another explanation states that the conversion stage is the period of transfer of rights or credit that has been issued for and on behalf of each PIR participant farmer by signing a credit agreement with the Bank.

\footnotetext{
${ }^{14}$ Tim Khusus Proyek Perkebunan Inti Rakyat, Direktorat Jenderal Perkebunan, Perusahaan Inti Rakyat Perkebunan-Pelaksanaan dan Penilaian, (Jakarta: unpublished, 1 November 1992), page 5-2.

${ }^{15}$ Ibid.,page. 4-7 dan 4-8.
} 
The mechanism of repayment of the loan installments of PIR Farmers participating farmers is explained as follows. ${ }^{16}$

a. For regular repayment of credit installments, but still remaining a portion of farmer's income for maintenance costs and sources of welfare for farmers and their families, the amount of credit installments amounting to 30 percent is deducted from the income of the farmers' gross production to the core company (before costs are deducted, fertilizers, pesticides, and others). ${ }^{17}$

b. To speed up the repayment of its debt, it is possible that farmers pay more than 30 percent of their loan installments. However, payments are not justified at once. This is intended to prevent the sale of participating farmers' land to other parties. Payment at the same time is only possible with Local PIRs whose heirs do not reside on the site, causing the conversion to be unworkable.

c. During the installment payment period, participating farmers are subject to current year interest, so that the installments paid will be calculated by the bank with priority for the current year's interest payments (including interest arrears if any) and the remainder to reduce the farmers' principal debt. Therefore, in principle, the delay or reduction in the percentage of credit installments will result in interest arrears so that the farmer's credit burden becomes bigger.

d. In the event that the farmer participant has not been able to fulfill his obligation to pay a loan installment of 30 percent because the productivity is still low in the early years of the crop, it is possible that the participating farmers propose that the amount of the loan installment is below $30 \%$.

Thus, participating farmers in PIR Plantation get credit assistance for the cost of building gardens, houses, clearing of land and food crops, land certificates, garden roads and an overhead cost of 10 percent which will be borne by the participating farmers. Repayment of credit installments on time is one indicator of success in some of the objectives of the PIR Plantation Pattern. This can be achieved if the participating farmers' crops are well maintained so that high productivity is obtained, there is awareness of farmers, the application of good provisions issued by the Government and those that are funded in cooperation agreements between farmers and

\footnotetext{
${ }^{16}$ Direktorat Jenderal Perkebunan, op. cit., page 11-4 dan 11-5.

${ }^{17}$ Look M. Badrun, Tonggak Perubahan-Melalui PIR Kelapa Sawit Membangun Negeri, (Jakarta: Direktorat Jenderal Perkebunan dan Politeknik Kelapa Sawit Citra Widya Edukasi, 2010), page. 60.
} 
core companies. In addition, the success of participant farmers' loan repayment is very dependent on the relationship and togetherness of the core company and participating farmers, the active participation of farmers who are increasingly stable, the increase in income and the increasing role of farmer institutions both farmer groups and Village Unit Cooperatives.

Third, Extension to Participant Farmers. The final stage in the Plantation Core Estate and Smallholders mechanism is the post-conversion stage which includes the development of farming; harvesting, processing, and marketing of garden produce; and repayment of credit. The development of farming is meant to foster farming businesses that are directed towards achieving the socio-economic welfare goals of PIR Plantation participant farmers, through counseling and training approaches to participating farmer groups in order to improve adequate skills and knowledge of participating farmers in utilizing available production factors optimally and can achieve the desired level of productivity and income. The objectives of farming development include (a) forming independent farmers in utilizing all factors of production; (b) improve and direct the potential of participating farmers to reach the level of farm productivity through groups; (c) guiding participating farmers as responsible bank customers. Guidance at the location of the Core People's Plantation Company in the context of developing farmer participating farmers includes technical and non-technical coaching. Technical guidance on plantations is carried out by the plantation office and the core company, while the development of food farming or diversification is carried out by the Department of Agriculture by placing field extension workers (PPL). Non-technical guidance includes social and cultural coaching carried out by relevant agencies between the Ministry of Transmigration, the Ministry of Cooperatives and Regional Government. In addition, mental spiritual development is also carried out to improve the mental and physical abilities of the farmers so that they are expected to be able to solve the problems faced. ${ }^{18}$

In Plantation Core Estate and Smallholders, technical guidance and counseling in conducting garden cultivation in accordance with the technology recommended by the core company to participating farmers is indeed one of the rights of participating farmers and is one of the duties and obligations of the core company. ${ }^{19}$ In addition, technical guidance and

\footnotetext{
${ }^{18}$ Direktorat Jenderal Perkebunan, op. cit.

19 ibid, page. 3-13. Also look Instruksi Presiden (Inpres) Nomor 1 Tahun 1986 dated 3 March 1986. Sofyandi Wirianata, Seperempat Abad Pengembangan Proyek PIR Perkebunan Nusantara VIII-Dalam Tinjauan Antara Harapan dan Kenyataan, Bandung, unpublished, May 2003, page 37. Direktorat Jenderal Perkebunan, op.citpage 6-8 - 6-9. Peraturan Daerah Tingkat I Propinsi Jawa Barat Nomor 6 Tahun 1992 tentang
} 
counseling for participating farmers from core companies is one of the important elements in Plantation Core Estate and Smallholders. This is as stated in the definition of Plantation Core Estate and Smallholders themselves. ${ }^{20}$ Besides being the obligation of the core company, guidance and counseling to improve the ability to participate farmers is also the duty of the Directorate General of Plantation. ${ }^{21}$

Fourth, Sales of Oil Palm Fruit Participant Farmers. The post-conversion activities in the PIR Planting Pattern mechanism include one of the harvesting, processing, and marketing of the farmers' farm produce. ${ }^{22}$ The three components are related to each other in relation to the conversion phase. Harvesting or collection of garden produce is an effort to reap the results of the business carried out when the plants are ready to be harvested, by maintaining and paying attention to the sustainability of plantation production. Meanwhile, processing is an effort to preserve or process production into a form that is ready for sale. While marketing is an effort to sell crops or the results of processing to get money as income for farming. The purpose of these activities is to increase the added value of raw materials processed and improve quality, diversify processed products and increase yield utilization, and provide processed materials that meet processing and profitable requirements. Then the results must be oriented to market demand. ${ }^{23}$

After the conversion period, PIR Perkebunan participant farmers obtain income from crop yields on land for plantations, yard, and land for food crops. All plant products from the participating farmer's land are sold to the core company with a price formula set by the Government, for example for oil palm fruit calculated based on the formula for the price of Fresh Fruit Bunches (FFB) set by the Government.

The purchase price of palm oil fresh fruit bunches produced by farmers is based on a formula. Pricing and procedures for purchasing Fresh Fruit Bunches involve various aspects of activities and interests that need to be harmonized and directed in order to be able to support the continuation of mutually beneficial relationships between participating farmers and core companies. The formula needs to be established because the business relationship of the core company position tends to be stronger as a single buyer in remote areas. Participant farmers need to get protection from monopolistic practices that weaken the bargaining position of farmers. To

Penyelenggaraan Perusahaan Inti Rakyat Perkebunan, Lembaran Daerah Propinsi Daerah Tingkat I Jawa Barat tanggal 23 Oktober 1993 Nomor 4 Seri C, Article 6.

${ }^{20}$ Surat Keputusan Menteri Pertanian Nomor 668/Kpts/KB.510/10/, op.cit.

${ }^{21}$ Ibid, article 12 dan 13.

${ }^{22}$ Milton Crosby, op. cit., page. 39 dan 40.

${ }^{23}$ Ibid., page. 40 dan 41. 
benefit the parties, the selling price of the farmers' farm produce to the core company follows the price formula set by the Government. ${ }^{24}$

As mentioned in the previous paragraph that the relationship between the parties, including between large plantations as the core company and participating farmers. in the People's Core Company Plantation is a straightforward and regulated relationship through a certain mechanism and a cooperation agreement is made. Some types of cooperation agreements referred to, among others, are Cooperation Agreements on Harvested Payments and Repayment of Participant Farmer Loans between Banks and Core Companies, Agreement between Project Leader / Nucleus Company and Participant Farmers regarding Management of Farmers and Participant Farmers Loans, Credit Agreement between Banks and Participant Farmers, and the Production and Sale Agreement of Palm Oil Fresh Fruit Bunches between Core Companies and Participating Farmers. Therefore, in this connection must pay attention to the terms of the partnership pattern, the rights, and obligations of the core companies and participating farmers, the legal requirements of the agreement and the principles in the contract law. So that it can create legal certainty, justice, usefulness, and balance of rights and for the parties involved. Because in practice, the position of farmers participating tends to be weaker than the core company or bank. Likewise, respect for the property rights of both also needs attention.Several clauses in the cooperation agreement in the implementation of the Core People's Plantation Company indicate the existence of state interference.

First, the Harvest Results from Purchase-Payment Cooperation Agreement and Repayment of Participant Farmer Loans. As one example of this is the agreement between the Branch Manager of the Bank Rakyat Indonesia and the PT. Perkebunan. This contact considers:

a. Assignment Letter of the Ministry of Agriculture No. KB 520/541/Mentan/IX/89 dated 2 September 1989.

b. Smallholder Development Agreement between Directorate-General of Agriculture and PT. Perkebunan No. RC 320/E.8.49/06.87 at 10 Juni 1987 and No. 911-73/b.3/RC 320 at 4 Mei 1988.

c. Ministerial Decree of Agriculture No. 668/Kpts/KB.510/1985 at 4 Oktober 1985 on General Guidelines of Plantation Core Estate and Smallholders.

\footnotetext{
${ }^{24}$ M. Badrun, op. cit., page 57
} 
d. Ministerial Decree of Agriculture No. 43 Kpts/KB.320/2/1987 at 2 Februari 1987 on Guideline and Formula of Purchasing Price on Fresh Fruit Bunches (TBS) of Palm Production of Farmer Members of Plantation Core Estate and Smallholders.

e. Directorate-General Decree of Agriculture No. 3/KB.210/SK/DJBUN/6/87 at 27 Juni 1987 on Technical Guideline of Rendemen and Quality Control of Harvest Yields and Guidelines of Purchase and Payment of Fresh Fruit Bunches (TBS) of Palm Production of Farmer Members of Plantation Core Estate and Smallholders.

f. Production Contract between Perjanjian Produksi antara PT. Perkebunan with Farmer Members of Plantation Core Estate and Smallholders.

g. Credit Contract between Directorate-General of Agriculture and Directors of Executive Bank.

h. Power of Attorney of the Chief Executive Director of PT. Perkebunan to the Site Manager regarding the Signing of Partnership Contract on Purchase and Payment of Harvest Yields and Farmers' Credit Payment.

Both parties agreed to enter into a cooperation agreement in the framework of purchasing and paying for crop yields as well as paying off the credit of farmers participating in the project of the Core People's Plantation Company (PIR-BUN) whose arrangements are set out in the articles of agreement. A statement by first considering matters which are regulated in the provisions stipulated by the Government above shows the existence of State interference in the agreement to protect the interests of the weak party. This is in accordance with the thoughts of P.S. Atiyah, if the parties do not have the same training position, the State needs to intervene to protect the weak party. So that the agreement is expected to bring good to the parties, including those who are weak.

Other clauses that indicate the existence of State interference, namely Article 2 paragraph (1) which stipulates that "The core company is obliged to buy all the crop yields of staple crops cultivated by participating farmers with quality according to the core company requirements and prices according to Government provisions". The clause in Article 2 paragraph (1) of this agreement which states that the price of the main crop of participating farmers according to Government provisions indicates that there is State interference in this agreement to protect the interests of participating farmers who are considered as weak parties. This is based on the consideration that the participating farmers' basic income is from oil palm fruit from their garden. The position of the core company is stronger as a single buyer in remote areas, so 
farmers participating need to get protection from monopolistic practices that weaken the bargaining position of farmers. Therefore, in order for the purchase of participating farmers 'farm produce to benefit farmers, the selling price of participating farmers' oil palm fruit to the core company in the agreement is regulated following the price formula set by the Government. ${ }^{25}$

Second, the Production and Sale Agreement of Palm Oil Fresh Fruit Bunches between Core Companies and Participating Farmers. Production and Sale and Purchase Agreement for Fresh Fruit Bunches (FFB) is an agreement to buy and sell oil palm fruit between core companies and participating farmers through farmer groups or Village Unit Cooperatives with PIR Plantation Patterns.Article 5 of the existing agreement contains provisions concerning the obligation of participating farmers that "Farmers must sell all Fresh Fruit Bunches to the Core Company to be processed and marketed and the Nucleus Company must purchase FFB delivered by Participating Farmers at prices according to the Government's stipulations. The core company has the right to buy all of the participating farmers' oil palm fruit to meet the raw material needs of the processing plant owned. While the participating farmers get guaranteed marketing of their garden products. This shows that in fact, the contents of the agreement on the main will of the parties are balanced or fair, where the parties both benefit. Article 5 of this agreement stipulates that the core company is obliged to buy oil palm fruit belonging to the participating farmers at prices in accordance with the provisions stipulated by the Government. The existence of this article shows that the State intervened to protect the interests of the participating farmers who were considered weak parties.

Article 9 regulates the force majeure that "In the event that part or all of the obligations of both parties cannot be carried out due to reasons other than the ability of both parties (force majeure), then this shall be conveyed to the relevant Government agencies for the steps to resolve them". The existence of State interference can also be seen in the provisions of article 9. This is in accordance with the thoughts of P.S. Atiyah that if the parties do not have the same training position, the State needs to intervene to protect the weak party. So that the agreement is expected to bring goodness to the parties, including farmers.

\section{Conclusion}

Plantation Core Estate and Smallholders aim to create a mutually beneficial, intact and sustainable relationship between large plantations and smallholder plantations. Relationships in

\footnotetext{
${ }^{25}$ M. Badrun, op. cit., page 57.
} 
Plantation Core Estate and Smallholders have a theme or spirit of partnership, but the relationship is not family-based but is carried out in a straightforward manner through certain mechanisms regulated in legislation and cooperation agreements. Mechanisms in Plantation Core Estate and Smallholders are prepared by involving state interference as outlined in the legislation. The agreements in Plantation Core Estate and Smallholders also contain provisions that indicate the existence of State interference. This is in accordance with the thoughts of P.S. Atiyah that if the parties do not have the same bargaining position, the State needs to intervene to protect the weak parties, so that the mechanism and agreements in Plantation Core Estate and Smallholders are expected to bring benefits to the parties including Plantation Core Estate and Smallholders participating farmers.

\section{References}

Cahyadi, E. R., \& Waibel, H. (2013). Is Contract farming in the Indonesian oil palm industry pro-poor? Journal of Southeast Asian Economies, 62-76.

Euler, M., Schwarze, S., Siregar, H., \& Qaim, M. (2016). Oil palm expansion among smallholder farmers in Sumatra, Indonesia. Journal of Agricultural Economics, 67(3), 658-676.

Gatto, M., Wollni, M., Asnawi, R., \& Qaim, M. (2017). Oil palm boom, contract farming, and rural economic development: Village-level evidence from Indonesia. World Development, $95,127-140$.

Glover, D., \& Kusterer, K. (2016). Small farmers, big business: contract farming and rural development. Springer.

Kessler, F. (1943). Contracts of Adhesion--Some Thoughts About Freedom of Contract. Colum. L. Rev., 43, 629.

$\mathrm{Li}, \mathrm{T} . \mathrm{M}$. (2017). The price of un/freedom: Indonesia's colonial and contemporary plantation labor regimes. Comparative Studies in Society and History, 59(2), 245-276.

M. Badrun. (2010). Tonggak Perubahan-Melalui PIR Kelapa Sawit Membangun Negeri. Jakarta: Direktorat Jenderal Perkebunan dan Politeknik Kelapa Sawit Citra Widya Edukasi.

Milton Crosby. (1995). Implementasi Kebijaksanaan Perkebunan Plantation Core Estate and Smallholders (PIR Bun) Di Kabupaten Dati II Sintang-Studi Kasus Pada PIR Khusus I Sintang. Tesis Program Pascasarjana Universitas Gadjah Mada, unpublished. 
Minot, N. (2018). Contract Farming in Developing Countries: Patterns, Impact, and Policy Implications (6-3). Case Studies in Food Policy for Developing Countries: Domestic Policies for Markets, Production, and Environment, 2, 37.

P.S. Atiyah. (2003). The Rise and Fall of Freedom of Contract. Oxford: Clarendon Press.

Sofyandi Wirianata. (2003). Seperempat Abad Pengembangan Proyek PIR Perkebunan Nusantara VIII-Dalam Tinjauan Antara Harapan dan Kenyataan. Bandung, unpublished.

Surat Keputusan Menteri Pertanian Nomor 668/Kpts/KB.510/10/1985 tentang Petunjuk Umum Pelaksanaan Proyek Perusahaan Inti Rakyat Perkebunan.

Surat Keputusan Menteri Pertanian Nomor 60/Kpts/KB.510/2/1998 tentang Pembinaan dan Pengendalian Pengembangan Perkebunan Plantation Core Estate and Smallholders, tanggal 19 Februari 1998.

Sutan Remy Sjahdeini. (1993). Kebebasan Berkontrak Dan Perlindungan Yang Seimbang Bagi Para Pihak Dalam Perjanjian Kredit Bank Di Indonesia. Jakarta: Institut Bankir Indonesia.

Tim Khusus Proyek Perkebunan Inti Rakyat, Direktorat Jenderal Perkebunan, Perusahaan Inti Rakyat Perkebunan-Pelaksanaan dan Penilaian, (Jakarta: unpublished, 1 Nopember 1992),

Trebilcock, M. J. (1997). The limits of freedom of contract. Harvard University Press. 